\title{
First Molecular Characterization of Cryptosporidium spp. in Patients Living with HIV in Honduras
}

\author{
Sergio Betancourth ${ }^{1}$, Osman Archaga ${ }^{1}$, Wendy Moncada ${ }^{2}$, Vilma Rodríguez ${ }^{2}$ and Gustavo Fontecha ${ }^{1, * *(1)}$ \\ 1 Microbiology Research Institute, Universidad Nacional Autónoma de Honduras, \\ Tegucigalpa 11101, Honduras; sergiobet94@gmail.com (S.B.); osman.archagav@gmail.com (O.A.) \\ 2 Servicio de Atención Integral para Pacientes que Viven con VIH/SIDA-Instituto Nacional Cardiopulmonar, \\ Tegucigalpa 11101, Honduras; karely.mn@gmail.com (W.M.); vil_crl@yahoo.com (V.R.) \\ * Correspondence: gustavo.fontecha@unah.edu.hn; Tel.: +504-33935443
}

check for updates

Citation: Betancourth, S.; Archaga, O.; Moncada, W.; Rodríguez, V.; Fontecha, G. First Molecular Characterization of Cryptosporidium spp. in Patients Living with HIV in Honduras. Pathogens 2021, 10, 336. https:// doi.org/10.3390/pathogens10030336

Academic Editors: Sébastien Besteiro and Luiz Shozo Ozaki

Received: 3 February 2021

Accepted: 2 March 2021

Published: 13 March 2021

Publisher's Note: MDPI stays neutral with regard to jurisdictional claims in published maps and institutional affiliations.

Copyright: (c) 2021 by the authors. Licensee MDPI, Basel, Switzerland. This article is an open access article distributed under the terms and conditions of the Creative Commons Attribution (CC BY) license (https:// creativecommons.org/licenses/by/ $4.0 /)$.

\begin{abstract}
Cryptosporidiosis is one of the most important causes of gastroenteritis in the world, especially in low- and middle-income countries. It is caused by the Apicomplexan parasite Cryptosporidium spp., and mainly affects children and immunocompromised people, in whom it can pose a serious threat to their health, or even be life threatening. In Honduras, there are no data on parasite species or on molecular diversity or Cryptosporidium subtypes. Therefore, a cross-sectional study was conducted between September 2019 and March 2020 for the molecular identification of Cryptosporidium spp. in 102 patients living with HIV who attended a national hospital in Tegucigalpa. Stool samples were analyzed by direct microscopy, acid-fast stained smears, and a rapid lateral flow immunochromatographic test. All samples that tested positive were molecularly analyzed to identify the species and subtype of the parasite using three different markers: gp60, cowp, and 18Sr. PCR products were also sequenced. Four out of 102 samples (3.92\%) were positive for Cryptosporidium parvum, and all were assigned to subtype IIa. These findings suggest a possible zoonotic transmission in this population.
\end{abstract}

Keywords: Cryptosporidium spp; C. parvum; gp60; 18S ribosomal; cowp; HIV / AIDS; Honduras

\section{Introduction}

New HIV infections worldwide have decreased by $40 \%$ since the peak in 1998 . However there are currently more than 38 million people living with HIV (PLHIV) with 1.7 million new infections occurring in 2019 [1]. Low- and middle-income countries (LMICs) show only a modest achievement in reducing the burden of this disease due mainly to limited antiretroviral (ARV) coverage and lack of access to health services. In Honduras, more than 23,000 PLHIV were reported in 2019, and although the number of deaths from AIDS has decreased significantly in the country, the number of people newly infected with HIV has remained stable in the last decade [2].

People living with HIV/AIDS suffer from numerous and frequent opportunistic infections, many of which pose a serious threat to their health and are life threatening. Cryptosporidiosis is one of the most common causes of gastroenteritis in immunocompromised people $[3,4]$. The etiologic agent, Cryptosporidium spp., is an Apicomplexan protozoan with opportunistic behavior. In healthy, immunocompetent people, it usually causes an asymptomatic infection, or it is the cause of self-limited intestinal symptoms. Conversely, in immunocompromised people, it causes severe diarrhea, fever, nausea, vomiting and dehydration that can lead to the death of the patient. The infection can also progress to chronic diarrhea [5], which can persist for several months in patients with CD4 counts below 50-100 cells $/ \mathrm{mm}^{3}[6,7]$. These infections pose an additional challenge for the clinician and the patient because treatment in PLHIV has low efficacy.

The Cryptosporidium mechanism of transmission can be either direct or indirect. The former is fecal-oral, through the ingestion of infectious oocysts shed by infected hosts; the 
latter is through the ingestion of oocysts present in contaminated water or food. Oocysts are highly resistant to natural environmental conditions and even to the chemical treatments used to make drinking water potable, such as chlorine [8]. Since the parasite has the ability to infect a wide range of vertebrate hosts, including humans and farm animals, especially livestock, human infections can have anthroponotic or zoonotic origins $[9,10]$. In LMICs, cases of cryptosporidiosis are frequent in children under 5 years of age and transmission is believed to follow mostly an anthroponotic pattern. In contrast, outbreaks of zoonotic origin are most frequent in industrialized countries [11].

A growing number of Cryptosporidium species have been reported to cause infection in humans and other vertebrate hosts $[12,13]$. The two most frequently reported species in humans and among PLHIV are C. hominis and C. parvum [14,15], but many other zoonotic species are also commonly found among immunocompromised patients $[13,16]$. Some authors suggest that the severity of the clinical manifestations of cryptosporidiosis could be associated with different species [17]. Furthermore, C. hominis has been associated with a more anthroponotic transmission, while C. parvum and other species are primarily associated with zoonotic transmission, although to a lesser extent they can also be transmitted between humans [18]. Hence, it is important to determine the parasite at the species level, either in a geographic region or between specific biological populations. Since identification of the parasite species cannot be done by routine clinical laboratory methods (e.g., modified Ziehl-Neelsen or any acid-fast stain), it is necessary to resort to genetic methods based on molecular markers such as the gp60 gene or the sequencing of the $18 \mathrm{~S}$ ribosomal fragment. Not only these techniques allow species identification, but also serve to classify each species into families and subtypes [19-21].

Studies determining the prevalence of cryptosporidiosis in PLHIV in the Central American region are very scarce, and to our knowledge no previous studies are available genotyping the parasite in Honduras. Therefore, in this study, we investigated for the first time Cryptosporidium species and genotypes in HIV-infected individuals in Honduras to increase understanding of Cryptosporidium epidemiology in the country.

\section{Results}

\subsection{Clinical and Epidemiological Data}

One hundred and two adult patients living with the human immunodeficiency virus (PLHIV) with or without diarrhea and seeking routine medical care were recruited for this study. All patients voluntarily agreed to participate after providing their written informed consent. Sixty participants were male $(58.82 \%)$ and 42 were female $(41.18 \%)$. The average age was 44.02 years, in an age ranging from 24 to 66 years. Most of the participants (68.6\%) resided in the department of Francisco Morazán, where the Honduran capital, Tegucigalpa, is located, while 32 participants came from 12 other departments of the country (Figure 1). With regard to drinking water, the majority (55\%) of the participants indicated that they drank bottled water on a regular basis and $40 \%$ reported drinking tap water (Figure 2).

The majority $(86.3 \%)$ of the participants were on antiretroviral treatment at the time of recruitment. Diarrhea in the past week was reported by 29 participants $(28.4 \%)$. Of these, 16 patients reported having symptoms for less than a week, while 13 patients reported a longer duration. Patients with diarrhea reported an average of five bowel movements per day, with a range between one and 15 . Other less common clinical symptoms included fever $(25.49 \%)$, cough $(27.45 \%)$, nausea $(10.78 \%)$, and abdominal pain $(16.66 \%)$ (Table 1$)$.

Ninety-four $(92.15 \%)$ participants had a recent count of CD4+ T cells in their medical record. The average number of CD4 cells was $266 / \mathrm{mm}^{3}$ ( $\mathrm{SD}=283$; and range 3 to 1000). The mean CD4 lymphocyte count among patients with diarrhea was 239 cells $/ \mathrm{mm}^{3}$ (range, 7 to 921 ), while the mean for patients without diarrhea was 310 cells $/ \mathrm{mm}^{3}$ (range, 3 to 1000). The average time since patients were diagnosed as HIV positive was 6.8 years $(\mathrm{SD}=6$ years; and range 2 days to 20 years). 


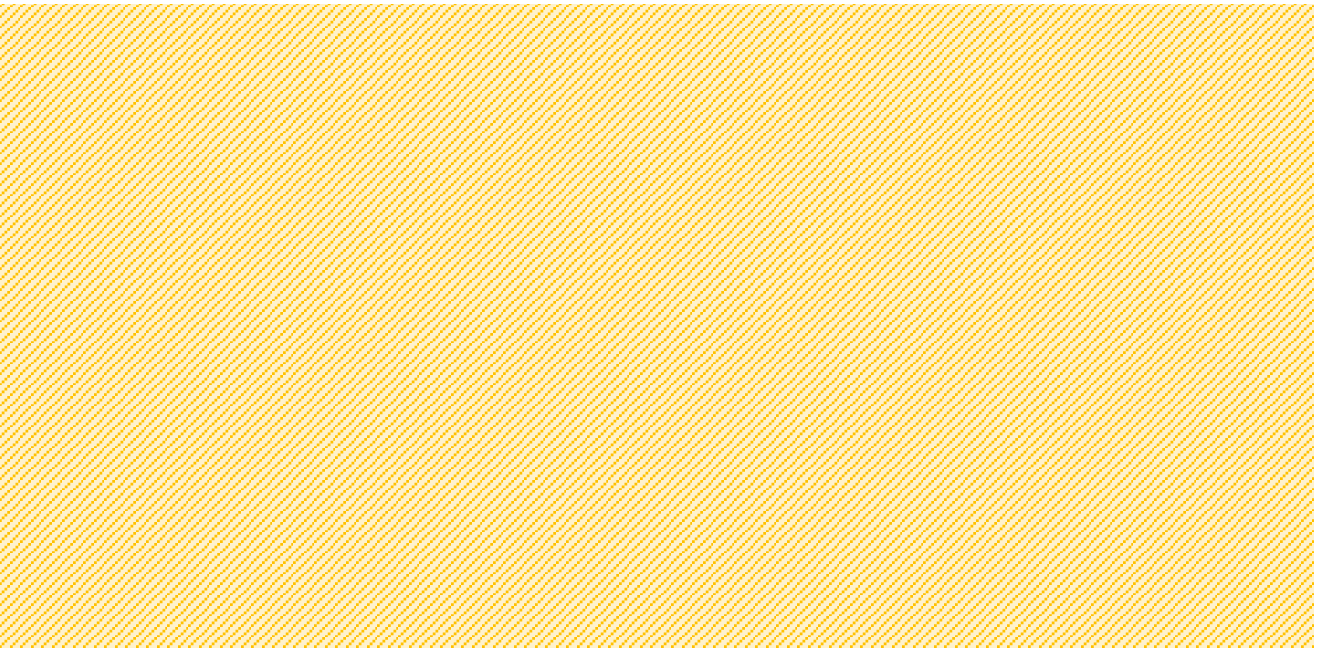

Figure 1. Geographical origin of the study participants.

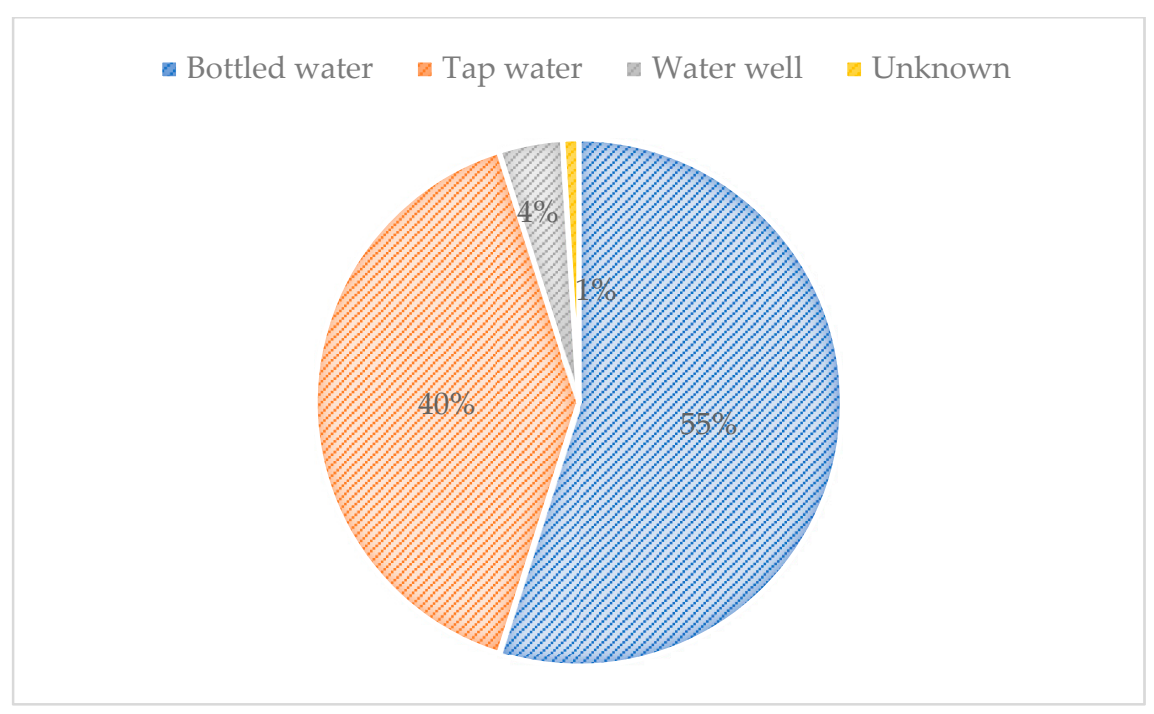

Figure 2. Source of drinking water of the study participants.

Table 1. Clinical and laboratory characteristics of the study population $(n=102)$.

\begin{tabular}{cccc}
\hline $\begin{array}{c}\text { Clinical and Laboratory } \\
\text { Findings }\end{array}$ & Present $\boldsymbol{n} \mathbf{( \% )}$ & Absent $\boldsymbol{n} \mathbf{( \% )}$ & Unknown $\boldsymbol{n}(\mathbf{\%})$ \\
\hline Antiretroviral therapy & $88(86.27)$ & $12(11.76)$ & $2(1.96)$ \\
Diarrhea of at least 3 days & $29(28.43)$ & $73(71.57)$ & $0(0)$ \\
Fever & $26(25.49)$ & $75(73.52)$ & $1(0.98)$ \\
Cough & $28(27.45)$ & $73(71.57)$ & $1(0.98)$ \\
Nausea & $11(10.78)$ & $90(88.23)$ & $1(0.98)$ \\
Abdominal pain & $17(16.66)$ & $84(82.35)$ & $0.98)$ \\
Mucus in stool & $27(26.47)$ & $75(73.52)$ & $0(0)$ \\
Macroscopic parasites & $0(0)$ & $102(100)$ & $0(0)$ \\
White blood cells in stool & $2(1.96)$ & $100(98.04)$ & $9(8.82)$ \\
Yeasts in stool & $71(69.61)$ & $22(21.57)$ & $0(0)$ \\
Intestinal parasites & $32(31.37)$ & $70(68.62)$ & \\
\hline
\end{tabular}

${ }^{1}$ Presence of one or more parasites, including Cryptosporidium spp.

\subsection{Coproparasitological Analysis}

All participants submitted a stool sample for coproparasitological analysis. The consistency of most of the samples was soft or well formed $(81.4 \%)$, while $18.6 \%$ of the 
stools were watery. Only $26.5 \%$ of the samples presented mucus in the macroscopic analysis, and none showed the presence of blood or macroscopic parasites.

To evaluate the presence of oocysts, samples were processed with the modified ZiehlNeelsen stain (Kinyoun) and with an immunochromatographic rapid diagnostic test (RDT) used for the simultaneous detection of Cryptosporidium spp. and Giardia intestinalis. The Kinyoun stain revealed that four patients out of $102(3.92 \%)$ were infected with Cryptosporidium spp. and one patient was infected with Cystoisospora belli $(0.98 \%)$. The RDT also showed the presence of cryptosporidiosis in the same four patients. Two cases of giardiasis in another two patients were also detected by the RDT. The concordance between the Kinyoun stain and the RDT for the diagnosis of cryptosporidiosis was 100\%.

Other intestinal infections were detected in 32 participants (Table 1 and Figure 3). Most infections were caused by commensals protozoa, but five potential pathogenic parasites were identified: Giardia intestinalis, Ascaris lumbricoides, Trichuris trichiura, Cystoisospora belli and Entamoeba histolytica/dispar. Four patients were polyparasitized by two or three microorganisms. Two of the four patients with Cryptosporidium were coinfected with Blastocystis hominis or Iodamoeba butschlii.

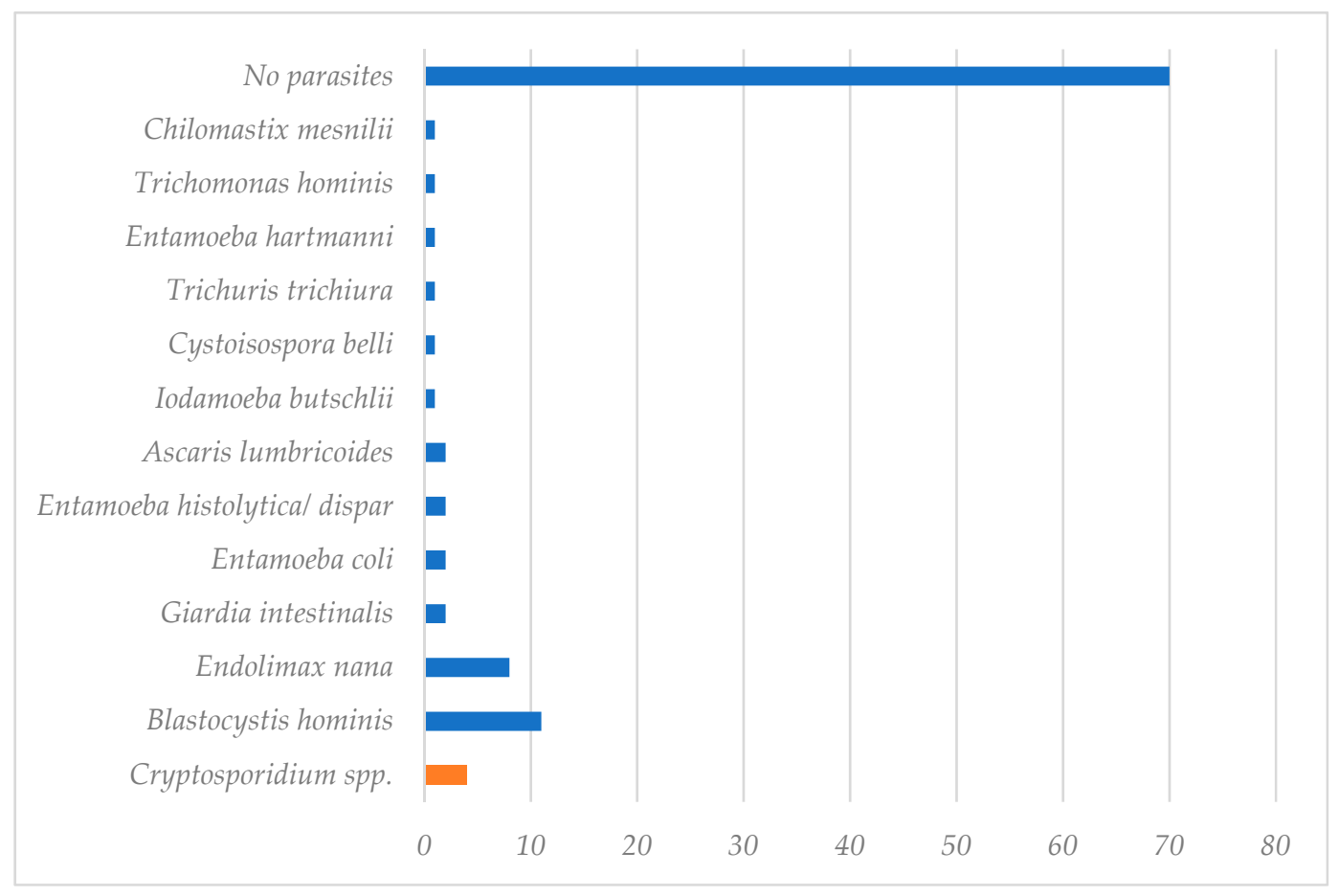

Figure 3. Number and species of intestinal parasites found in the participating individuals.

\subsection{Clinical and Laboratory Data of Four Patients Infected by Cryptosporidium spp.}

Three of the four Cryptosporidium-infected patients were women. All were residents of Tegucigalpa; three indicated that the source of drinking water was bottled water and one drank tap water. Three of them had diarrhea at the time of collecting the fecal sample; three were on antiretroviral therapy and one had a fever. The CD4+ cell range for those four patients was $18-185 / \mathrm{mm}^{3}$ (Table 2).

\subsection{Molecular Analysis}

Three molecular markers were used for the diagnosis of Cryptosporidium species: the gp60 gene, cowp gene and the $18 \mathrm{~S}$ ribosomal fragment. The amplification by nested PCR of the gp60 gene is capable of differentiating C. parvum and C. hominis by means of a size polymorphism (Figure 4a) [19]. The four samples showed the presence of $C$. parvum with a product of $848 \mathrm{bp}$. The isolates belong to the IIaA15G2R1 subtype, with 15 TCA triplets 
and 2 TCG triplets in the trinucleotide repeat region, one ACATCA repetitive sequence, and a conserved region that matches IIa [21-23]. The cowp gene was also amplified through nested PCR and subsequently digested with the restriction enzyme RsaI to differentiate both species of Cryptosporidium [24]. All four samples revealed a restriction pattern of 413 bp and 129 bp, which was consistent with C. parvum (Figure 4b,c). The third molecular marker was the $18 \mathrm{~S}$ ribosomal gene [10] (Figure $4 \mathrm{~d}$ ). The amplified region of this locus does not show size polymorphisms that could help to differentiate between parasite species and was therefore necessary to sequence the PCR product.

Table 2. Demographic, clinical and laboratory data of the four patients with cryptosporidiosis.

\begin{tabular}{ccccccc}
\hline Patient & Sex & Age & $\begin{array}{c}\text { Drinking } \\
\text { Water }\end{array}$ & Diarrhea & $\begin{array}{c}\text { CD4 Cell } \\
\text { Count/mm }\end{array}$ & ARV \\
\hline 1 & F & 46 & Bottled & $>3$ days & 38 & Yes \\
2 & F & 32 & Tap water & No & 40 & Yes \\
3 & F & 35 & Bottled & 3 days & 185 & Yes \\
4 & M & 44 & Bottled & $<3$ days & 18 & No \\
\hline
\end{tabular}

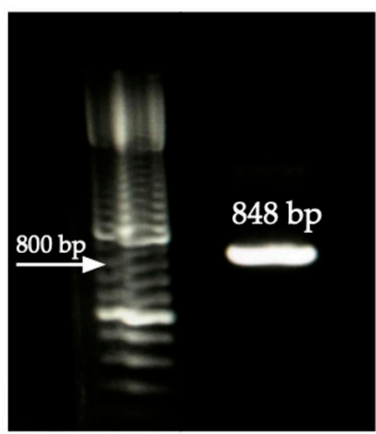

(a)

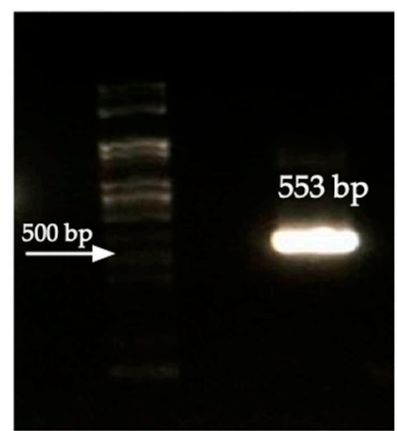

(b)

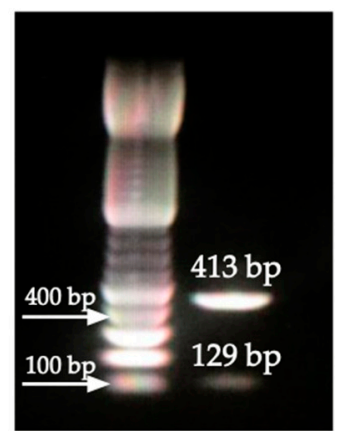

(c)

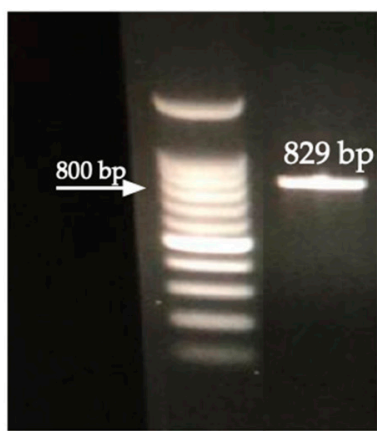

(d)

Figure 4. Agarose electrophoresis showing: (a) PCR product of the gp60 gene; (b) PCR amplification of the cowp gene; (c) Digestion of the PCR product of the cowp gene using RsaI; (d) PCR amplification of the 18S ribosomal fragment.

The amplification products of the three genes were sequenced to confirm the parasite's species. When analyzed with the NCBI BLAST tool, all sequences from the four positive participants confirmed that the species was C. parvum. All sequences showed a maximum nucleotide identity of $98.8 \%$ with nucleotide sequences deposited in the GenBank. No nucleotide differences were found between similar sequences. All sequences were deposited in the GenBank database under accession numbers MW493664-7 (18Sr), MW561213-6 (cowp) and MW561217-20 (gp60).

\section{Discussion}

Intestinal infections by Cryptosporidium spp. are the leading cause of chronic diarrhea in immunocompromised people [5,25-27] and represent a threat to the lives of the population living with HIV [28,29]. In this study, the presence of Cryptosporidium spp. was investigated in a population of HIV-positive adults and a prevalence of 3.92\% (4/102) was found. Several studies have aimed to estimate the prevalence of cryptosporidiosis in immunocompromised populations in different countries [5,30-36]; however, the results are heterogeneous even with data collected within the same country $[7,37,38]$. The discrepancies between the studies could be attributed in part to their methodological design; however, all the components of the epidemiological triad, which includes the interaction between the host, the parasite and the environment, could be behind these inconsistencies.

Some authors report a prevalence similar to that found in this study. In a crosssectional study conducted among 346 immunocompromised patients in Iran, the prevalence 
of cryptosporidiosis among HIV / AIDS patients was $4.6 \%$ and the overall prevalence in the study population was 3.5\% [39]. Another study carried out in Indonesia among adult HIV / AIDS patients with chronic diarrhea and without antiretroviral therapy showed a prevalence of $4.9 \%$ [38]. Due to the heterogeneity of the information available in the literature on the prevalence of cryptosporidiosis in PLHIV, it is difficult to explain the relatively low prevalence found in this study. However, it could be attributed to the availability of antiretroviral therapies and the consumption of potable drinking water in most cases. Future studies should be carried out to overcome some limitations of this study, such as the small sample size and, therefore, the impossibility of associating cryptosporidiosis with the CD4 count and symptoms of the patients.

The diagnosis of cryptosporidiosis is usually made by microscopic observation of oocysts in the stool after staining with acid-fast methods. More technically complex methods such as ELISA and quantitative PCR have been proposed as an alternative for routine diagnosis $[33,40,41]$, but microscopy remains the gold standard, especially in lowand middle-income country (LMIC) settings. In this study, all samples were analyzed by the Kinyoun stain and an immunochromatographic lateral flow assay (rapid diagnostic test, RDT). Both methods had the same results on the same samples with $100 \%$ agreement. A recent cross-sectional study conducted among children with diarrhea from four African countries compared this RDT with a diagnostic panel that included PCR and qPCR tests as gold standards. The authors concluded that the RDT had a very low sensitivity compared to molecular approaches [42]. On the other hand, other authors compared two RDTs against PCR as the reference method in patient samples from three hospitals in Madrid, finding $100 \%$ sensitivity and specificity in the RDT used in our study [43]. Although the number of samples analyzed in the present study was small, it is possible to suggest that RDTs could be a good method to be used routinely for the detection of Cryptosporidium spp. due to their speed and ease of procedure. However, it is also necessary to consider the moderately higher cost of laboratories in Honduras.

Other intestinal parasites were also reported in this study. More than $31 \%$ of the participants revealed at least one parasite, commensal or pathogen. A previous study that included 133 people with HIV in Honduras reported an overall prevalence of intestinal parasites of $67 \%$ [44]. Cryptosporidium was not found on that occasion. Another study conducted in 1998 among 52 PLHIV and 48 HIV-negative people in San Pedro Sula, Honduras, reported that $55 \%$ of all participants and $49 \%$ of HIV-positive patients harbored at least one intestinal parasite. These authors found that Cryptosporidium spp. and Strongyloides stercoralis were present exclusively among people with HIV, while the prevalence of other extracellular parasites was significantly higher in the comparison group [45]. Despite the high prevalence of intestinal parasites reported in these studies, there do not seem to be significant differences with respect to the general population of the country, whose inhabitants, particularly children, have historically reported high prevalences of intestinal parasitism [46-50].

To date, more than 20 species have been described, but C. hominis and C. parvum are the two most common in humans [14,15]. In this study, all four cases were caused by C. parvum. In addition to the high heterogeneity of the data found in the literature on the prevalence of cryptosporidiosis in PLHIV, there are discrepancies regarding the most common species that cause infection in this population. Most studies report $C$. hominis as the most prevalent species $[13,36,39,51-54]$, while in other studies $C$. parvum is the most frequent $[16,55-58]$. This discrepancy does not appear to be associated with a geographical distribution, since both groups of reports include studies carried out on three or four continents. Given that C. hominis is a more selective parasite and C. parvum is more generalist, an anthroponotic transmission versus a zoonotic transmission seems to be the most accepted argument among the authors to explain the phenomenon $[9,11,18]$.

Some studies have suggested that Cryptosporidium genotypes could influence the epidemiology and severity of symptoms [17], and the hypervariable marker gp60 has become the most widely used to genotype and classify the parasite [11]. Following this 
classification, the four isolates in this study belong to the IIaA15G2R1 subtype. This result was corroborated by the three molecular markers, which shows that all can be used successfully to genotype the parasite, although it is preferable to use gp60 in the future to generate data that better adhere to world trends. An interesting result of this study is that all four cases of cryptosporidiosis were caused by the same subtype of the parasite, although there was no epidemiological link between the patients. Future studies with a larger sample and a "One Health" approach with a multidisciplinary team could shed light on the genetic diversity of Cryptosporidium in Honduras [59]. Since this is the first report of the parasite genotypes in Honduras, it is not possible to compare our result with similar reports. However, the genotype IIaA15G2R1 of C. parvum has been reported in all continents and is the one with the greatest distribution in both cattle and humans $[15,19,21]$. It has also been described as the hyper-transmissible subtype [60]. These data would support the hypothesis of a zoonotic transmission among the participants of this study.

\section{Materials and Methods}

Study population and sample collection. This was a cross-sectional study in adult patients living with HIV who attended routine follow-up medical care at the Infectious Diseases department of the Instituto Nacional Cardiopulmonar (INCP), from Tegucigalpa Honduras. This hospital was selected because it specializes in the healthcare of PLHIV/AIDS, both in outpatient services and in hospitalization. The selected patients were over the age of 21 years old and enrolled between September 2019 and March 2020. All patients who agreed to participate voluntarily, regardless of their health status, were included in the study. A questionnaire was applied to collect demographic information that included: name, sex, age, place of residence, source of drinking water, clinical symptoms that included gastroenteritis, daily bowel movement frequency, fever, cough, nausea, vomiting, and abdominal pain. In addition, the last CD4+ T lymphocyte count, antiretroviral treatment status, and duration of HIV infection were extracted from patient's medical records. Each patient had to provide a single stool sample the same day they were enrolled. The physician provided a sterile container for collection of the stool sample. The samples were transported to the laboratory of the National Autonomous University of Honduras (UNAH) for analysis the same day the patients were enrolled.

Ethical consideration. Informed consent was obtained from all patients who voluntarily decided to participate in the study. Participants' personal information was encrypted to anonymize the stool samples and registration documents. This study was approved by two institutional ethics boards: the Ethics Committee of the INCP (0-21 CE-INCP-2019) and the Ethics Committee of the Maestría de Enfermedades Infecciosas y Zoonóticas-UNAH (03-2019).

Coproparasitological analysis, Kinyoun stain and rapid diagnostic test. A single stool sample was obtained from each participant and analyzed the same day as collection. All samples were examined by light microscopy, first with saline and iodine solutions in search of any intestinal parasite, and secondly on a stained smeared slide using a modified ZiehlNeelsen acid-fast stain (BK Kinyoun Kit, Química Analítica Aplicada, Tarragona, Spain) for the specific detection of coccidian oocysts. Further, a commercial one-step rapid lateral flow immunochromatographic test was performed (CerTest Crypto + Giardia combo card test, BIOTEC S.L., Zaragoza, Spain) according to the manufacturer's instructions for the simultaneous detection of Cryptosporidium spp. and Giardia spp. All samples that were positive for Cryptosporidium spp. under microscopic analyses or rapid diagnostic testing were stored at $-20^{\circ} \mathrm{C}$ for further DNA extraction.

DNA extraction. Frozen samples were thawed at room temperature for DNA extraction. Genomic DNA was extracted using the QIAamp DNA Stool Mini Kit (Qiagen, Düsseldorf, Germany) following the manufacturer's instructions. A $200 \mu \mathrm{L}$ aliquot of extracted DNA was stored at $-20^{\circ} \mathrm{C}$ for further use.

Molecular markers. Positive samples with Cryptosporidium oocysts demonstrated by Kinyoun or the RDT were subjected to molecular analysis. The molecular identification of 
Cryptosporidium species was performed using the following three markers: the gp60 gene, cowp gene, and the $18 \mathrm{~S}$ ribosomal fragment (Figure 5).

GP60

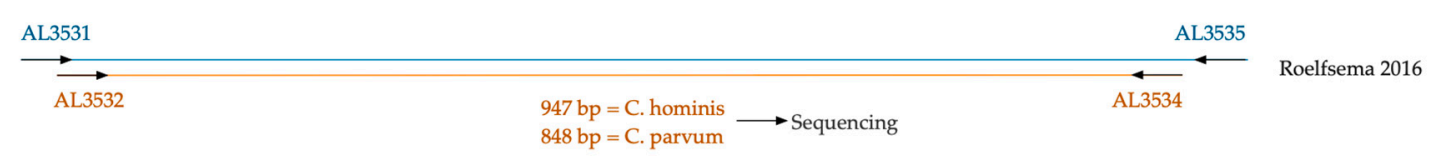

(a)

COWP

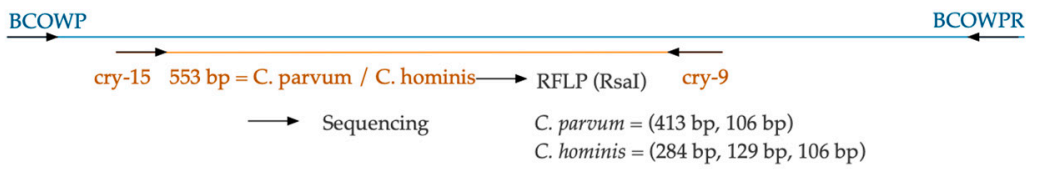

Gharieb 2018

\section{(b)}

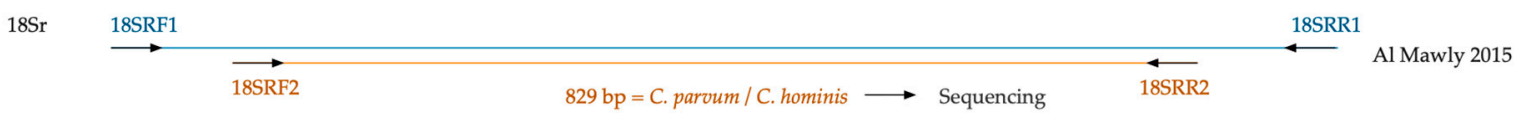

(c)

Figure 5. Working algorithm of three molecular markers for the identification of Cryptosporidium spp. (a) Nested PCR of the gp60 gene [19]; (b) Nested PCR of the cowp gene, and PCR-RFLP for species identification [24]; (c) Nested PCR of the $18 \mathrm{~S}$ ribosomal gene [10].

Amplification of the gp60 gene. A nested PCR was performed for the amplification of a fragment of the gp60 gene using primers and cycling conditions as described by Roelfsema et al. [19] with some modifications. Both reactions were performed in $25 \mu \mathrm{L}$ total volume that contained $12.5 \mu \mathrm{L}$ of GoTaq ${ }^{\circledR}$ Green Master Mix (Promega, Madison, WI, USA), $1.0 \mu \mathrm{L}$ of each primer at a $10 \mu \mathrm{M}$ concentration, nuclease-free water, and 1-2 $\mu \mathrm{L}$ of the DNA template. Reactions were amplified by an initial denaturation at $95^{\circ} \mathrm{C}$ for $3 \mathrm{~min}, 35$ cycles at $94{ }^{\circ} \mathrm{C}$ for $45 \mathrm{~s}$, annealing temperature for $45 \mathrm{~s}$, and $72{ }^{\circ} \mathrm{C}$ for $1 \mathrm{~min}$, with a final extension at $72{ }^{\circ} \mathrm{C}$ for $10 \mathrm{~min}$. Amplification products from nested reactions were visualized by $1 \%$ agarose gel electrophoresis with ethidium bromide. The primer sequences are described in Table 3.

Table 3. Sequences of the primers used for the amplification of three molecular markers.

\begin{tabular}{|c|c|c|}
\hline Gene & $\begin{array}{l}\text { Primers for the } \\
\text { Nested PCR }\end{array}$ & Sequence $\left(5^{\prime}-3^{\prime}\right)$ \\
\hline \multirow[t]{4}{*}{ gp60 gene } & AL3531F & ATAGTCTCCGCTGTATTC \\
\hline & AL3535R & GGAAGGAACGATGTATCT \\
\hline & AL3532F & TCCGCTGTATTCTCAGCC \\
\hline & AL3534R & GCAGAGGAACCAGCATC \\
\hline \multirow[t]{4}{*}{$18 \mathrm{~S}$ ribosomal gene } & 18SRF1 & GTTAAACTGCGAATGGCTCA \\
\hline & 18SRR1 & CCATTTCCTTCGAAACAGGA \\
\hline & 18SRF2 & CTCGACTTTATGGAAGGGTTG \\
\hline & 18SRR2 & CСТCСАATCTCTAGTTGGCATA \\
\hline \multirow[t]{4}{*}{ cowp gene } & BCOWPF & ACCGCTTCTCAACAACCATCTTGTCСТC \\
\hline & BCOWPR & CGCACCTGTTCCCACTCAATGTAAACCC \\
\hline & Cry-15 & GTAGATAATGGAAGAGATTGTG \\
\hline & Cry-9 & GGACTGAAATACAGGCATTATCTTG \\
\hline
\end{tabular}


Amplification and PCR-Restriction Fragment Length Polymorphism (RFLP) of the cowp gene. For the amplification of the cowp gene, a nested PCR was performed with a subsequent digestion of amplicons. Primers and cycling conditions were used as described by Gharieb et al. [24] with some modifications. Both PCR reactions were performed in $50 \mu \mathrm{L}$ total volume that contained $25 \mu \mathrm{L}$ of GoTaq $^{\circledR}$ Green Master Mix (Promega, Madison, WI, USA), $2.0 \mu \mathrm{L}$ of each primer (Table 2) at a concentration of $10 \mu \mathrm{M}$, nucleasefree water, and 1-2 $\mu \mathrm{L}$ of DNA template. Both amplification reactions were performed by an initial denaturation at $95{ }^{\circ} \mathrm{C}$ for $5 \mathrm{~min}, 35$ cycles at $94{ }^{\circ} \mathrm{C}$ for $30 \mathrm{~s}$, annealing temperature for $30 \mathrm{~s}$, and $72{ }^{\circ} \mathrm{C}$ for $30 \mathrm{~s}$, with a final extension at $72{ }^{\circ} \mathrm{C}$ for $10 \mathrm{~min}$. Amplicons obtained from the second reaction were visualized by $1 \%$ agarose gel electrophoresis with ethidium bromide. A 553-bp fragment was expected for both Cryptosporidium parvum and C. hominis. Next, an RFLP enzymatic digestion was performed using RsaI (Promega, Madison, WI, USA) following the manufacturer's instructions for $2 \mathrm{~h}$. Fragments obtained from enzymatic digestion were visualized by $1.5 \%$ agarose gel electrophoresis with ethidium bromide.

Amplification of the $18 S$ rRNA locus. A nested PCR was also performed for the amplification of the 18Sr gene using primers and cycling conditions as described by $\mathrm{Al}$ Mawly et al. [10] with some modifications. Reactions were performed in $50 \mu \mathrm{L}$ total volume that contained $25.0 \mu \mathrm{L}$ of GoTaq ${ }^{\circledR}$ Green Master Mix (Promega, Madison, WI, USA), $2.0 \mu \mathrm{L}$ of each primer (Table 2) at a $10 \mu \mathrm{M}$ concentration, $2.0 \mu \mathrm{L}$ of Bovine Serum Albumin (BSA) $(10 \mathrm{mg} / \mu \mathrm{L})$, nuclease-free water, and $1-2 \mu \mathrm{L}$ of the DNA template. Both reactions were amplified by an initial denaturation at $95^{\circ} \mathrm{C}$ for $2 \mathrm{~min}$, followed by 35 cycles at $95^{\circ} \mathrm{C}$ for $1 \mathrm{~min}$, annealing temperature for $1 \mathrm{~min}$, and $72{ }^{\circ} \mathrm{C}$ for $1 \mathrm{~min}$, with a final extension at $72{ }^{\circ} \mathrm{C}$ for $10 \mathrm{~min}$. Amplification products from second PCR reactions were visualized by $1 \%$ agarose gel electrophoresis with ethidium bromide.

Sequencing and sequence analysis. The amplification products of the three markers were sequenced on both strands using the same primers used for the second round of amplification in the nested PCR. Purification and sequencing services were provided by Psomagen (https://lims.psomagen.com, accessed on 16 January 2021). The sequences were edited with the Geneious ${ }^{\circledR}$ 9.1.7 software (Biomatters Ltd., Auckland, New Zealand) and were deposited in the National Center for Biotechnology Information (NCBI; https: / / www.ncbi.nlm.nih.gov, accessed on 23 January 2021). All sequences were submitted as queries to NCBI via the BLAST tool under default parameters to determine percent identity relative to the most similar sequences available in the GenBank nucleotide collection. The sequences were deposited in the NCBI GenBank. The gp60 gene sequences were classified according to the subfamilies proposed in the literature [21-23]. Subtype assignment is based on the number of trinucleotide repeats and other repetitive sequences. Subtype families are named Ia, etc., for C. hominis and IIa, etc., for C. parvum [61].

\section{Conclusions}

This is the first report of the genetic characterization of Cryptospordium spp. at the species and subtype levels in HIV-positive people in Honduras. C. parvum IlaA15G2R1 was the only subtype detected and suggests a possible zoonotic transmission in this population. Further research on Cryptosporidium should focus on animals and other human populations to expand our knowledge of the subject and to clarify transmission routes.

Author Contributions: Conceptualization, G.F.; methodology, O.A., S.B. and G.F.; validation, G.F., W.M. and S.B.; formal analysis, S.B.; investigation and patient assessment/recruitment, S.B., V.R. and W.M.; resources, G.F.; data curation, S.B. and G.F.; writing-original draft preparation, G.F.; writing-review and editing, G.F., W.M. and S.B.; supervision, G.F.; project administration, G.F.; funding acquisition, G.F. All authors have read and agreed to the published version of the manuscript.

Funding: This research received no external funding. 
Institutional Review Board Statement: The study was conducted according to the guidelines of the Declaration of Helsinki and approved by two institutional ethics boards: the Ethics Committee of the INCP (0-21 CE-INCP-2019) and the Ethics Committee of the Maestría de Enfermedades Infecciosas y Zoonóticas-UNAH (03-2019).

Informed Consent Statement: Informed consent was obtained from all patients who voluntarily decided to participate in the study.

Data Availability Statement: Data are contained within the article.

Acknowledgments: The authors wish to acknowledge the collaboration of the medical, laboratory and nursing staff of the Tegucigalpa Cardiopulmonary Institute (INCP), as well as the collaboration provided by the patients and study participants. We also thank Andrés Ortiz (UNAH) for his help with the bioinformatics. A special thanks to Ana Lourdes Sánchez (Brock University) for the critical reading and suggestions made to the manuscript.

Conflicts of Interest: The authors declare no conflict of interest.

\section{References}

1. UNAIDS. Global HIV \& AIDS Statistics-2020 Fact Sheet: UNAIDS. 2021. Available online: https://www.unaids.org/en/ resources / fact-sheet (accessed on 24 January 2021).

2. World Health Organization. Honduras: HIV Country Profile 2019: WHO. 2020. Available online: https://cfs.hivci.org/countryfactsheet.html (accessed on 24 January 2021).

3. Mohebali, M.; Yimam, Y.; Woreta, A. Cryptosporidium infection among people living with HIV/AIDS in Ethiopia: A systematic review and meta-analysis. Pathog. Glob. Health 2020, 114, 183-193. [CrossRef]

4. Ajjampur, S.R.; Asirvatham, J.R.; Muthusamy, D.; Gladstone, B.P.; Abraham, O.C.; Mathai, D.; Ward, H.; Wanke, C.; Kang, G. Clinical features \& risk factors associated with cryptosporidiosis in HIV infected adults in India. Indian J. Med. Res. 2007, 126, 553-557.

5. Utami, W.S.; Murhandarwati, E.H.; Artama, W.T.; Kusnanto, H. Cryptosporidium Infection Increases the Risk for Chronic Diarrhea Among People Living With HIV in Southeast Asia: A Systematic Review and Meta-Analysis. Asia Pac. J. Public Health 2020, 32, 8-18. [CrossRef] [PubMed]

6. Wang, R.J.; Li, J.Q.; Chen, Y.C.; Zhang, L.X.; Xiao, L.H. Widespread occurrence of Cryptosporidium infections in patients with HIV / AIDS: Epidemiology, clinical feature, diagnosis, and therapy. Acta Trop. 2018, 187, 257-263. [CrossRef]

7. Darlan, D.M.; Rozi, M.F.; Andriyani, Y.; Yulfi, H.; Saragih, R.H.; Nerdy, N. Cryptosporidium Sp. Findings and Its Symptomatology among Immunocompromised Patients. Open Access Maced. J. Med. Sci. 2019, 7, 1567-1571. [CrossRef]

8. Zahedi, A.; Ryan, U. Cryptosporidium-An update with an emphasis on foodborne and waterborne transmission. Res. Vet. Sci. 2020, 132, 500-512. [CrossRef] [PubMed]

9. King, P.; Tyler, K.M.; Hunter, P.R. Anthroponotic transmission of Cryptosporidium parvum predominates in countries with poorer sanitation: A systematic review and meta-analysis. Parasit Vectors 2019, 12, 16. [CrossRef]

10. Al Mawly, J.; Grinberg, A.; Velathanthiri, N.; French, N. Cross sectional study of prevalence, genetic diversity and zoonotic potential of Cryptosporidium parvum cycling in New Zealand dairy farms. Parasit Vectors 2015, 8, 240. [CrossRef] [PubMed]

11. Xiao, L. Molecular epidemiology of cryptosporidiosis: An update. Exp. Parasitol. 2010, 124, 80-89. [CrossRef]

12. Alves, M.; Xiao, L.; Sulaiman, I.; Lal, A.A.; Matos, O.; Antunes, F. Subgenotype analysis of Cryptosporidium isolates from humans, cattle, and zoo ruminants in Portugal. J. Clin. Microbiol. 2003, 41, 2744-2747. [CrossRef] [PubMed]

13. Sannella, A.R.; Suputtamongkol, Y.; Wongsawat, E.; Caccio, S.M. A retrospective molecular study of Cryptosporidium species and genotypes in HIV-infected patients from Thailand. Parasit Vectors 2019, 12, 91. [CrossRef] [PubMed]

14. Dey, A.; Ghoshal, U.; Agarwal, V.; Ghoshal, U.C. Genotyping of Cryptosporidium Species and Their Clinical Manifestations in Patients with Renal Transplantation and Human Immunodeficiency Virus Infection. J. Pathog. 2016, 2016, 2623602. [CrossRef] [PubMed]

15. Leary, J.K.O.; Blake, L.; Corcoran, G.D.; Sleator, R.D.; Lucey, B. Increased diversity and novel subtypes among clinical Cryptosporidium parvum and Cryptosporidium hominis isolates in Southern Ireland. Exp. Parasitol. 2020, 218, 107967. [CrossRef] [PubMed]

16. Lim, Y.A.; Iqbal, A.; Surin, J.; Sim, B.L.; Jex, A.R.; Nolan, M.J.; Smith, H.V.; Gasser, R.B. First genetic classification of Cryptosporidium and Giardia from HIV/AIDS patients in Malaysia. Infect. Genet. Evol. 2011, 11, 968-974. [CrossRef]

17. Cama, V.A.; Bern, C.; Roberts, J.; Cabrera, L.; Sterling, C.R.; Ortega, Y.; Gilman, R.H.; Xiao, L. Cryptosporidium species and subtypes and clinical manifestations in children, Peru. Emerg. Infect. Dis. 2008, 14, 1567-1574. [CrossRef]

18. Slapeta, J. Cryptosporidiosis and Cryptosporidium species in animals and humans: A thirty colour rainbow? Int. J. Parasitol. 2013, 43, 957-970. [CrossRef]

19. Roelfsema, J.H.; Sprong, H.; Cacciò, S.M.; Takumi, K.; Kroes, M.; Van Pelt, W.; Kortbeek, L.M.; Van Der Giessen, J.W.B. Molecular characterization of human Cryptosporidium spp. isolates after an unusual increase in late summer 2012. Parasit Vectors 2016, 9 , 138. [CrossRef] 
20. Essid, R.; Menotti, J.; Hanen, C.; Aoun, K.; Bouratbine, A. Genetic diversity of Cryptosporidium isolates from human populations in an urban area of Northern Tunisia. Infect. Genet. Evol. 2018, 58, 237-242. [CrossRef]

21. Chalmers, R.M.; Robinson, G.; Elwin, K.; Elson, R. Analysis of the Cryptosporidium spp. and gp60 subtypes linked to human outbreaks of cryptosporidiosis in England and Wales, 2009 to 2017. Parasit Vectors 2019, 12, 95. [CrossRef] [PubMed]

22. Sulaiman, I.M.; Hira, P.R.; Zhou, L.; Al-Ali, F.M.; Al-Shelahi, F.A.; Shweiki, H.M.; Iqbal, J.; Khalid, N.; Xiao, L. Unique endemicity of cryptosporidiosis in children in Kuwait. J. Clin. Microbiol. 2005, 43, 2805-2809. [CrossRef] [PubMed]

23. Strong, W.B.; Gut, J.; Nelson, R.G. Cloning and sequence analysis of a highly polymorphic Cryptosporidium parvum gene encoding a 60-kilodalton glycoprotein and characterization of its 15- and 45-kilodalton zoite surface antigen products. Infect. Immun. 2000, 68, 4117-4134. [CrossRef]

24. Gharieb, R.M.A.; Merwad, A.M.A.; Saleh, A.A.; Abd El-Ghany, A.M. Molecular Screening and Genotyping of Cryptosporidium Species in Household Dogs and In-Contact Children in Egypt: Risk Factor Analysis and Zoonotic Importance. Vector Borne Zoonotic Dis. 2018, 18, 424-432. [CrossRef] [PubMed]

25. Khan, A.; Shaik, J.S.; Grigg, M.E. Genomics and molecular epidemiology of Cryptosporidium species. Acta Trop. 2018, 184, 1-14. [CrossRef]

26. Udeh, E.O.; Obiezue, R.N.N.; Okafor, F.C.; Ikele, C.B.; Okoye, I.C.; Otuu, C.A. Gastrointestinal Parasitic Infections and Immunological Status of HIV/AIDS Coinfected Individuals in Nigeria. Ann. Glob. Health 2019, 85. [CrossRef]

27. Dong, S.; Yang, Y.; Wang, Y.; Yang, D.; Yang, Y.; Shi, Y.; Li, C.; Li, L.; Chen, Y.; Jiang, Q.; et al. Prevalence of Cryptosporidium Infection in the Global Population: A Systematic Review and Meta-analysis. Acta Parasitol. 2020, 65, 882-889. [CrossRef] [PubMed]

28. Selik, R.M.; Karon, J.M.; Ward, J.W. Effect of the human immunodeficiency virus epidemic on mortality from opportunistic infections in the United States in 1993. J. Infect. Dis. 1997, 176, 632-636. [CrossRef] [PubMed]

29. Aldeyarbi, H.M.; Abu El-Ezz, N.M.; Karanis, P. Cryptosporidium and cryptosporidiosis: The African perspective. Environ. Sci. Pollut. Res. Int. 2016, 23, 13811-13821. [CrossRef]

30. Shimelis, T.; Tassachew, Y.; Lambiyo, T. Cryptosporidium and other intestinal parasitic infections among HIV patients in southern Ethiopia: Significance of improved HIV-related care. Parasit Vectors 2016, 9, 270. [CrossRef]

31. Kaniyarakkal, V.; Mundangalam, N.; Moorkoth, A.P.; Mathew, S. Intestinal Parasite Profile in the Stool of HIV Positive Patients in relation to Immune Status and Comparison of Various Diagnostic Techniques with Special Reference to Cryptosporidium at a Tertiary Care Hospital in South India. Adv. Med. 2016, 2016, 3564359. [CrossRef]

32. Shimelis, T.; Tadesse, E. Performance evaluation of point-of-care test for detection of Cryptosporidium stool antigen in children and HIV infected adults. Parasit Vectors 2014, 7, 227. [CrossRef] [PubMed]

33. Jayalakshmi, J.; Appalaraju, B.; Mahadevan, K. Evaluation of an enzyme-linked immunoassay for the detection of Cryptosporidium antigen in fecal specimens of HIV/AIDS patients. Indian J. Pathol. Microbiol. 2008, 51, 137-138. [CrossRef]

34. Hung, C.-C.; Tsaihong, J.C.; Lee, Y.-T.; Deng, H.-Y.; Hsiao, W.-H.; Chang, S.-Y.; Chang, S.-C.; Su, K.-E. Prevalence of intestinal infection due to Cryptosporidium species among Taiwanese patients with human immunodeficiency virus infection. J. Formos. Med. Assoc. 2007, 106, 31-35. [CrossRef]

35. Yulfi, H.; Fakhrur Rozi, M.; Andriyani, Y.; Masyithah Darlan, D. Prevalence of Cryptosporidium spp. and Blastocystis hominis in faecal samples among diarrheic HIV patients in Medan, Indonesia. Med Glas (Zenica) 2021, 18, 55-61. [CrossRef]

36. Karshima, S.N.; Karshima, M.N. Epidemiology of Cryptosporidium Infections among People Living with HIV/AIDS in Nigeria: Results of Systematic Review and Meta-analysis. Acta Parasitol. 2020, 1-5. [CrossRef]

37. Ajjampur, S.S.; Sankaran, P.; Kang, G. Cryptosporidium species in HIV-infected individuals in India: An overview. Natl. Med. J. India 2008, 21, 178-184. [PubMed]

38. Kurniawan, A.; Karyadi, T.; Dwintasari, S.; Sari, I.; Yunihastuti, E.; Djauzi, S.; Smith, H. Intestinal parasitic infections in HIV / AIDS patients presenting with diarrhoea in Jakarta, Indonesia. Trans. R. Soc. Trop. Med. Hyg. 2009, 103, 892-898. [CrossRef]

39. Izadi, S.; Mohaghegh, M.A.; Ghayour-Najafabadi, Z.; Azami, M.; Mirzaei, F.; Namdar, F.; Mohebali, M.; Wannigama, D.L.; Hejazi, S.H. Frequency and Molecular Identification of Cryptosporidium Species among Immunocompromised Patients Referred to Hospitals, Central Iran, 2015-2016. Iran J. Parasitol. 2020, 15, 31-39.

40. Den Hartog, J.; Rosenbaum, L.; Wood, Z.; Burt, D.; Petri, W.A., Jr. Diagnosis of multiple enteric protozoan infections by enzyme-linked immunosorbent assay in the Guatemalan highlands. Am. J. Trop. Med. Hyg. 2013, 88, 167-171. [CrossRef]

41. Shrivastava, A.K.; Panda, S.; Kumar, S.; Sahu, P.S. Two novel genomic DNA sequences as common diagnostic targets to detect Cryptosporidium hominis and Cryptosporidium parvum: Development of quantitative polymerase chain reaction assays, and clinical evaluation. Indian J. Med. Microbiol. 2020, 38, 430-439. [CrossRef] [PubMed]

42. Manouana, G.P.; Lorenz, E.; Ngwese, M.M.; Moure, P.A.N.; Ascofaré, O.M.; Akenten, C.W.; Amuasi, J.; Rakotozandrindrainy, N.; Rakotozandrindrainy, R.; Mbwana, J.; et al. Performance of a rapid diagnostic test for the detection of Cryptosporidium spp. in African children admitted to hospital with diarrhea. PLoS Negl. Trop. Dis. 2020, 14, e0008448. [CrossRef] [PubMed]

43. Gutierrez-Cisneros, M.J.; Martinez-Ruiz, R.; Subirats, M.; Merino, F.J.; Millan, R.; Fuentes, I. Assessment of two commercially available immunochromatographic assays for a rapid diagnosis of Giardia duodenalis and Cryptosporidium spp. in human fecal specimens. Enferm. Infecc. Microbiol. Clin. 2011, 29, 201-203. [CrossRef] [PubMed]

44. Kaminsky, R.G.; Soto, R.J.; Campa, A.; Baum, M.K. Intestinal parasitic infections and eosinophilia in an human immunedeficiency virus positive population in Honduras. Mem. Inst. Oswaldo Cruz. 2004, 99, 773-778. [CrossRef] 
45. Lindo, J.F.; Ager, A.L.; Klaskala, W.I.; Palmer, C.J.; Baum, M.K.; De Gourville, E.M.; Dubon, J.M.; Solo-Gabriele, H. Intestinal parasitic infections in human immunodeficiency virus (HIV)-positive and HIV-negative individuals in San Pedro Sula, Honduras. Am. J. Trop. Med. Hyg. 1998, 58, 431-435. [CrossRef]

46. Naceanceno, K.S.; Matamoros, G.; Gabrie, J.A.; Bottazzi, M.E.; Sanchez, A.; Mejia, R. Use of Multi-Parallel Real-Time Quantitative PCR to Determine Blastocystis Prevalence and Association with Other Gastrointestinal Parasite Infection in a Rural Honduran Location. Am. J. Trop. Med. Hyg. 2020, 102, 1373-1375. [CrossRef]

47. Kaminsky, R.G. Parasitism and diarrhoea in children from two rural communities and marginal barrio in Honduras. Trans. R. Soc. Trop. Med. Hyg. 1991, 85, 70-73. [CrossRef]

48. Matamoros, G.; Rueda, M.M.; Rodríguez, C.; Gabrie, J.A.; Canales, M.; Fontecha, G.; Sanchez, A. High Endemicity of SoilTransmitted Helminths in a Population Frequently Exposed to Albendazole but No Evidence of Antiparasitic Resistance. Trop. Med. Infect. Dis. 2019, 4, 73. [CrossRef] [PubMed]

49. Sanchez, A.L.; Gabrie, J.A.; Usuanlele, M.T.; Rueda, M.M.; Canales, M.; Gyorkos, T.W. Soil-transmitted helminth infections and nutritional status in school-age children from rural communities in Honduras. PLoS Negl. Trop. Dis. 2013, 7, e2378. [CrossRef]

50. Torres, R.E.M.; Garcia, D.N.F.; Sandoval, G.A.F.; Santana, A.H.; Singh, P.; Bucheli, S.T.M.; Saboya, M.; Paz, M.Y. Prevalence and intensity of soil-transmitted helminthiasis, prevalence of malaria and nutritional status of school going children in honduras. PLoS Negl. Trop. Dis. 2014, 8, e3248. [CrossRef]

51. Pielok, Ł.; Nowak, S.; Kłudkowska, M.; Frąckowiak, K.; Kuszel, Ł.; Zmora, P.; Stefaniak, J. Massive Cryptosporidium infections and chronic diarrhea in HIV-negative patients. Parasitol. Res. 2019, 118, 1937-1942. [CrossRef]

52. Houpt, E.R.; Bushen, O.Y.; Sam, N.E.; Kohli, A.; Asgharpour, A.; Ng, C.T.; Calfee, D.P.; Guerrant, R.L.; Maro, V.; Ole-Nguyaine, S.; et al. Short report: Asymptomatic Cryptosporidium hominis infection among human immunodeficiency virus-infected patients in Tanzania. Am. J. Trop. Med. Hyg. 2005, 73, 520-522. [CrossRef] [PubMed]

53. De Lucca, P.; De Gaspari, E.N.; Bozzoli, L.M.; Funada, M.R.; Silva, S.O.D.S.; Iuliano, W.; Soares, R.M. Molecular characterization of Cryptosporidium spp. from HIV infected patients from an urban area of Brazil. Rev. Inst. Med. Trop. Sao Paulo. 2009, 51, 341-343. [CrossRef] [PubMed]

54. Gatei, W.; Barrett, D.; Lindo, J.F.; Eldemire-Shearer, D.; Cama, V.; Xiao, L. Unique Cryptosporidium population in HIV-infected persons, Jamaica. Emerg. Infect. Dis. 2008, 14, 841-843. [CrossRef] [PubMed]

55. Ghafari, R.; Rafiei, A.; Tavalla, M.; Moradi Choghakabodi, P.; Nashibi, R.; Rafiei, R. Prevalence of Cryptosporidium species isolated from HIV/AIDS patients in southwest of Iran. Comp. Immunol. Microbiol. Infect. Dis. 2018, 56, 39-44. [CrossRef]

56. Iqbal, A.; Lim, Y.A.; Surin, J.; Sim, B.L. High diversity of Cryptosporidium subgenotypes identified in Malaysian HIV/AIDS individuals targeting gp60 gene. PLoS ONE 2012, 7, e31139. [CrossRef]

57. Del Chierico, F.; Onori, M.; Di Bella, S.; Bordi, E.; Petrosillo, N.; Menichella, D.; Cacciò, S.M.; Callea, F.; Putignani, L. Cases of cryptosporidiosis co-infections in AIDS patients: A correlation between clinical presentation and GP60 subgenotype lineages from aged formalin-fixed stool samples. Ann. Trop. Med. Parasitol. 2011, 105, 339-349. [CrossRef]

58. Blanco, M.A.; Iborra, A.; Vargas, A.; Nsie, E.; Mba, L.; Fuentes, I. Molecular characterization of Cryptosporidium isolates from humans in Equatorial Guinea. Trans. R. Soc. Trop. Med. Hyg. 2009, 103, 1282-1284. [CrossRef]

59. Squire, S.A.; Ryan, U. Cryptosporidium and Giardia in Africa: Current and future challenges. Parasit Vectors 2017, $10,195$. [CrossRef]

60. Feng, Y.; Torres, E.; Li, N.; Wang, L.; Bowman, D.; Xiao, L. Population genetic characterisation of dominant Cryptosporidium parvum subtype IIaA15G2R1. Int. J. Parasitol. 2013, 43, 1141-1147. [CrossRef] [PubMed]

61. Leary, J.K.O.; Blake, L.; Corcoran, G.D.; Sleator, R.D.; Lucey, B. Development of novel methodology for the molecular differentiation of Cryptosporidium parvum gp60 subtypes via high resolution melting analysis. MethodsX 2020, 7, 101157. [CrossRef] [PubMed] 